FOLIA SCANDINAVICA VOL. 23 POZNAŃ 2017 DOI: $10.1515 / \mathrm{fsp}-2017-0004$

\title{
LINGUISTICS
}

\section{ADVERBIAL MARKERS OF MODALITY IN NORWEGIAN L1 AND L2 CONVERSATIONS}

\author{
PAULINA HORBOWICZ
}

Adam Mickiewicz University in Poznań

ABSTRACT. The aim of this paper is to investigate how second language speakers of Norwegian (henceforth Norwegian L2 speakers) differ in their use of modality expressions from native speakers (L1 speakers). As modality is a very broad subject, the main focus of the study is limited to one-word modal adverbs, such as kanskje 'maybe', and modal particles such as jo. The study compares the frequency of using different types of modal adverbials by L1 and L2 speakers, and their syntactic position. The implications of the study are two-fold. First of all, it is to contribute to the studies of the field of modality in Norwegian. The second implication is didactic, as describing the use of modal adverbials in Norwegian conversation can help devise right teaching materials to allow second language users achieve a more native-like competence in this respect.

\section{MODALITY}

Modality is a very broad notion, and as such, it is notoriously hard to define. Among many definitions, the most uncontroversial one seems to be that of 'modality (being) the grammaticization of speakers' (subjective) attitudes and opinions" (Bybee at al. 1994:176). It is a grammatical-semantic category, and languages differ as to which expressions of modality they employ. Grammatically speaking, the central notion is the verbal category of mood, whereas in semantics, one focuses on "certain auxiliary verbs like must, certain adverbs like maybe, and certain adjectives like possible" (Portner 2009:1-2). It seems, however, that the discussion of the semantics of modality has been dominated by the linguistic category of the modal auxiliaries (Nuyts 2016:39). Von Fintel claims that "it is traditional to 
use English modal auxiliaries or semimodal verbs as the primary source of illustrative examples" (von Fintel 2006:1). It seems therefore a legitimate conclusion that in the semantic studies on modality, the modal verb has been in the center of attention, somewhat at the expense of adverbs and other modal expressions.

There are several classifications of modality. Palmer (2001) suggests a dichotomous division into propositional modality and event modality, which again can be divided into two types: epistemic modality and evidential modality in the case of propositional modality, which "are concerned with the speaker's attitude to the truth-value or factual status of the proposition", and deontic and dynamic modality in the case of event modality, which "refer to events that are not actualized, events that have not taken place but are merely potential" (ibid.:8). While the two latter groups include mainly verbal markers (such as mood and modal verbs), the two former, constituting propositional modality, include a number of adverbial markers. The ones belonging to epistemic modality will be primarily dealing with the judgment about the factual status of a given proposition (for instance probability of an event taking place), whereas the ones classified as evidential indicate the evidence the speaker has for the factual status of the proposition. Nuyts sees evidential modality as more controversial than the epistemic, as "the borderline between epistemic and evidential forms may not be sharp, however, to the extent that some forms might be both epistemic and evidential" (Nuyts 2001:56). He in turn suggests including another type of modality, labeled as boulomaic, which "concerns an indication of the degree of the speaker's (or someone else's) liking or disliking (affectively) of the state of affairs" (Nuyts 2016:39). Nuyts claims that it is unclear why this category is not systematically included in the discussion of modal notions, but offers an explanation that it might be due to the fact that it is not one of the central modal meanings in West-European languages. Yet, one must admit that also in those languages "there are plenty of lexical (verbal, adverbial, adjectival) expression with this meaning" (op.cit.). Modal adverbs are frequently employed to express the epistemic, evidential and boulomaic modality.

Portner (2009) offers yet another classification, based rather on the scope rather than the meaning of a given modal expression. He speaks of sentential, sub-sentential and discourse modality (ibid.:2-3), and places the adverbs within the domain of sentential modality. While it is not an unproblematic decision, I will choose not to pursue this topic further, as it is not the main scope of this paper. 


\section{ADVERBIAL MARKERS OF MODALITY IN NORWEGIAN}

Adverbial markers of modality in Norwegian comprise a very varied group, including both single lexemes and whole phrases. In this paper the focus is on one-word adverbials, that is modal adverbs and modal particles. There is a great deal of syntactic variation in the studied group. Generally, modal adverbials should be placed in the middle-field (A), following the finite verb (SVA-order) in the main clause (1), and preceding it (SAV-order) in subordinate clause $(2)^{1}$.

(1) Det er egentlig bra. It is actually good.

(2) at det egentlig er bra. that it actually is good

In the same time, there are studies, which show that the SAV-order in subordinate clauses may indeed be subject to dialectal (Bentzen 2007) and modal (Sandøy 2008) variations.

Still, a great many of modal adverbials can also be placed in the front field, thus calling for inversion (the so called Verb2 rule, Faarlund et al. 1997:814).

(3) Egentlig er det bra.

Actually is it good

'Actually, it is good'

However, the front field position is not possible in case of unstressed modal adverbs such as nemlig or neppe, and the modal particles.

In addition, modal adverbials can appear in post field position (the term suggested by Fretheim (2015), in Norwegian sources one mainly speaks of ekstraposisjon), but with certain intonation restrictions (ibid.:814-5). That is true especially in the case of modal particles, which very often appear in the post field, though in this case they would be labelled rather as discourse or pragmatic markers rather than modal particles (more about this overlapping below).

A special case is the adverb kanskje 'maybe', which may appear in the initial position without the Verb2-inversion (in the prefield).

${ }^{1}$ In this paper, I will use the terms for the syntactic positions of the studied items suggested by Fischer and Alm (2013:53). The term 'prefield' differs from what is called 'front field' in that the former is optional, while the latter is obligatory. Following Fretheim (2015), I use the term 'post field' rather than 'end field', even though this choice is not uncontroversial. The scope of the paper, however, does not allow to elaborate on the matter. 
(4) Kanskje kommer de i morgen.

(5) Kanskje de kommer i morgen.

'Maybe they will come tomorrow'

Westergaard (2009) has found out that word order without inversion, as in example 5, is indeed the preferred one in Norwegian. Mac Donald (1990:60) mentions that the position of negation in the sentence with initial kanskje depends on the presence of inversion. If the word order is inverted, as in (4), the sentence follows the rules of the main clause word order, where the negation follows the finite verb, as in (6). However, when there is no inversion, the adverb requires a subordinate clause word order, that is SAV (7), while the SVA word order is to be seen as norm-breaching (8).

(6) Kanskje kommer de ikke.

(7) Kanskje de ikke kommer.

(8) *Kanskje de kommer ikke.

'Maybe they won't come'

Little has been so far written on the semantics and discursive use of Norwegian modal adverbs, whereas the topic of modal particles is somewhat better described, though mainly within the field of cognitive pragmatics (see for instance the special issue of Norsk lingvistisk tidsskrift 32/2014). Faarlund et al. (1997:815-27) offers a rough division of all sentence adverbials into related to context, truth value and empathy, that could somehow relate to the dichotomy of discourse marking and modal marking (Cuenca 2013:208), shown in figure 1 .

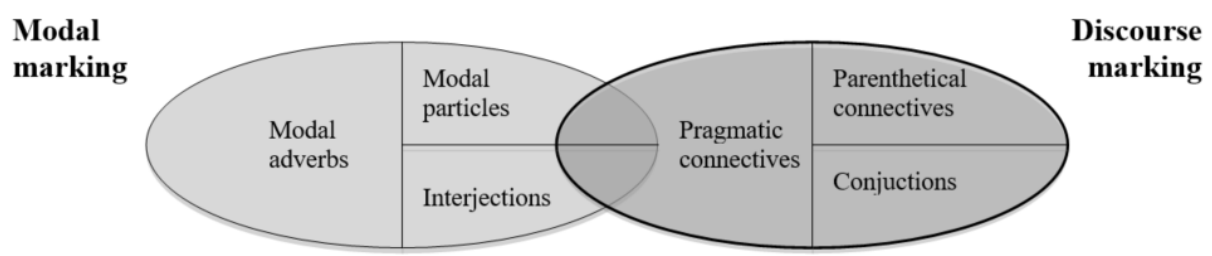

(Fig. 1) The modal-discourse marking space (after Cuenca 2013: 208).

In this model, the modal particles belong to the field of modal marking, but share some properties with the field of discourse marking. One criterium used to distinguish whether a given item belongs to the field of modal or discourse marking was its syntactic position. It has been claimed (Traugott 2007:141) that "formally, clause internal position is the modal particle position". Lind (1996) on the other hand, sees both the clause internal and the clause final position of the particle jo as modal, whereas the clause initial use is considered to be a discourse marker. This view is shared by Fretheim (2014:198), 
who says that the majority of particles can appear in both middle and post field position, with roughly the same meaning. Moreover, Aijmer (2013) has shown that some markers, such as English of course, can be seen as either an adverb, a modal particle or a discourse marker, depending on a variety of factors. This shows that within the category of modal and discourse marking one finds ambiguity and fuzzy boundaries.

The syntactic, semantic and functional variation observed among the members of the group may make mastering their formal and discursive features potentially difficult for second language speakers. Mac Donald (1990) suggests several "traps" within the domain of modality that L2 speakers may fall into: the word order after kanskje 'maybe', the meaning of sikkert 'surely', and the use and meaning of modal particles. Uri (1999) has studied the level of understanding modal particles by one advanced L2 user, in different syntactic positions. Her findings suggest that particles appearing in the middle field are better understood than those appearing in post field. Still, it is unclear whether those findings would be confirmed on a bigger study group. To my knowledge, the only study of modality in Norwegian as L2 that is based on actual language use is Svensson (2012) who investigates the modal expressions used in written language by participants of Bergenstesten, a national language test, collected in the so called ASK corpus (Norwegian as a second language corpus, cf. Tenfjord et al. 2009). Svensson has found the modal adverbs kanskje 'maybe' and sikkert 'surely', as well as modal particles nok, jo og vel, appear rather early, already on the A2-level of language command, and show a relatively high frequency of use throughout all levels (unfortunately, Svennson does not provide the exact number for the different modal markers). Another finding, which is hardly surprising, is that the repeatoire of the employed modal adverbials grew with each level of language command achieved. Still, even the most advanced language users differed when it comes to the variety and frequency of modal markers from the native controll group.

The goal of this paper is to investigate the types and the frequency of modal adverbials by L2 speakers. Basing on the reviewed literature, I have the following hypotheses regarding the L2 speakers' use of modal adverbials as compared to L1 speakers:

1. the range of the used adverbs will be more limited, with kanskje and sikkert appearing most frequently (cf. Svensson 2012);

2. there will be less variation in the syntactic position of kanskje, and some of the uses will be incoherent with the norm (cf. Mac Donald 1990);

3. taken into account how difficult it is to map out the different meanings and uses of modal particles, it is expected that their scope and/or frequency will be more limited (cf. Mac Donald 1990, Uri 1999). 


\section{MATERIAL AND METHOD}

The L2 conversations ${ }^{2}$ corpus (Horbowicz 2010) consists of 13 conversations with a total length of approximately 390 minutes. The average length of the conversation was thus 30 minutes. In each conversation there was one L1 and one L2 participant (with Polish as L1). The relations between the participants varied from being spouses (four conversations) to being work colleagues (four) or previously unacquainted with one another (five). The group of Polish informants is rather varied both when it comes to age (between 25 and 55), length of stay in Norway (between 1 and 16 years) and language command. However, they were all able to maintain the conversation for around 30 minutes, which shows their communicative skills to be sufficient.

The conversations in the control corpus stem from the Oslo corpus of spoken Norwegian (NoTa), hosted by Text Laboratory at the University of Oslo. The chosen conversations include those with the same types of relations as the $\mathrm{L} 2$ conversational corpus, though there is only one conversation among spouses there, seven between colleagues and five conversations between people previously unacquainted with one another. The data of the length of the conversations in the control corpus were unavailable, yet given the assumptions of the data collection (cf. Johannessen and Hagen 2008) one can assume that the total length is similar to the study group.

From each conversation I extracted the modal adverbs and particles used by each participant. In case of kanskje, which I assumed would be the most frequent modal adverb, I have also noted the position in the utterance (initial, medial or final) and whether this position may be seen as correct according to the norm.

\section{RESULTS}

I have analysed all the adverbs and particles found in the data (see table 1$)^{3}$. I have divided the adverbials into five groups, based partly on their meaning and partly on their discursive function.

2 The label L2 conversation is commonly used for a setting where at least one of the participants is a L2 speaker (cf. Gardner and Wagner 2004). The label is not uncontroversial for several reasons (cf. Wagner 1996, Sarangi 1994), but for the scope of this paper it is irrelevant to discuss the matter further.

${ }^{3}$ For the sake of clarity, the list with the number of occurrences in all conversations is presented in the attachment. 


\begin{tabular}{|c|l|l|}
\hline Number & Group label & Markers \\
\hline 1 & epistemic adverbs & $\begin{array}{l}\text { kanskje, sikkert, selvfølgelig, selvsagt, absolutt, } \\
\text { sannsynligvis, muligens }\end{array}$ \\
\hline 2 & evidential adverbs & egentlig, faktisk, virkelig, nemlig \\
\hline 3 & boulomaic adverbs & dessverre, forhåpentligvis, heldigvis \\
\hline 4 & particles & jo, nok, vel, da, visst \\
\hline 5 & alts $\stackrel{ }{ }$ \\
\hline
\end{tabular}

(Tab. 1) The groups of modal markers.

The evidential adverbs have a somewhat unclear status, for reasons mentioned above, cf. Nuyts (2001) in point 1. Group 4 are pragmatic particles jo, nok, vel, $d a$, visst, and group 5 is constituted by only one member altså 'therefore'. This item is traditionally considered to be a conjunctional adverb, and is thus seen as a part of the field of discourse marking, cf. figure 1 in which altsa $a$ would be situated in the group of pragmatic connectives. Yet, as Fischer\&Alm (2013) have shown ${ }^{4}$, altsa can function both as a discourse particle and a modal particle (possibly with an evidential meaning), depending on the position in the sentence. The two last groups of the studied markers are somewhat difficult to grasp, due the overlap of modal and discourse marking, described in point 3. Moreover, some of them may also appear in stressed position, and show then referential functions ( $d a$ as time-referring adverbial pronoun, not unlike the English 'then') or functioning as regular adverbs in nominal clauses (nok 'enough'). Such uses have been disregarded in this paper, as has the utterance initial use of jo. All the studied particles appear almost only in the sentence medial position, apart from $d a$, which is predominantly used in the post-field. As the boundaries between modal and discursive meaning of the particles and altså are somewhat fuzzy, I have chosen to include all instances of their use, even though some of them appear less prototypically modal than the others. I will discuss their functions in 5.2.

The total number of items analysed is 3655 in case of L1 conversations and 1352 in case of L2 conversations. Only 28\% of modal markers used in L2 conversations have been employed by L2 speakers (374 of 1352). It must be noted here that measuring the frequency of employing modal markers among all words used by a given speaker (comparable to Svensson's, 2012 study) proved to be very difficult, which is hardly surprising in case of dialogic spoken language material. Measuring the number of modal markers per turn was also impeded by formal criterions of deciding what constitutes a full turn. Instead, I focus on the relative frequency of the adverbs and particles among other modal markers. The exact number of occurrences of each modal marker can be found in the attachment.

${ }^{4}$ It is worth mentioning here that their study deals with Swedish alltså and German also, but their findings match the Norwegian use of altså as well. 


\subsection{THE TYPES OF MODAL ADVERBIALS USED IN L1 AND L2 TALK}

Figure 2 shows the frequency of different types of modal markers used by L1 and L2 speakers in both settings.

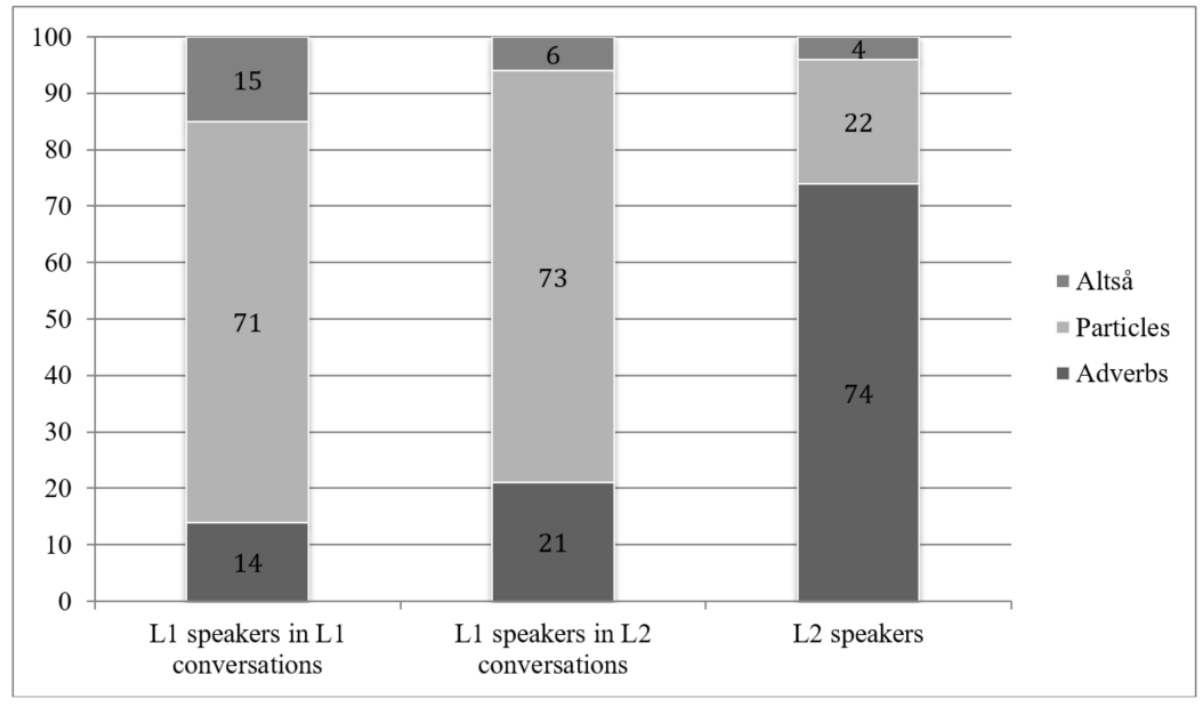

(Fig. 2) The distribution of the frequency of types of modal markers used by speakers in L1 and L2 setting (percent data).

The differences are clearly visible - while particles dominate the repertoire of native speakers' modal expression, the L2 speakers use predominantly adverbs. The L1 use of modal markers is quite consistent in both types of conversation (L1 and L2 setting), with a slight discrepancy found in the frequency of altså. As far as adverbs are concerned, all users clearly use epistemic modal markers the most, with evidential markers being the second. The adverbs classified as boulomaic appear only incidentally in the L1 and L2 language use, and constitute only $2 \%$ and $1 \%$ in the case of L1 speakers in L1 and L2 setting, respectively, while the frequency is $5 \%$ in the case of L2 speakers. This is a weak indication that L2 users use the boulomaic modal markers more frequently than L1 users. However, the data in this category is scarce, so it does not suffice to draw any significant conclusions. 


\subsection{THE USE OF EPISTEMIC MODAL ADVERBS}

\begin{tabular}{|l|c|c|c|}
\hline kanskje & $\begin{array}{c}\text { L1 conversation } \\
(\text { L1-A/B) }\end{array}$ & $\begin{array}{c}\text { L1 speakers } \\
\text { in L2 conversations } \\
(\text { L2-B) }\end{array}$ & $\begin{array}{c}\text { L2 speakers } \\
\text { (L2-A) }\end{array}$ \\
\hline sikkert & 58 & 68 & 76 \\
\hline other & 25 & 21 & 12 \\
\hline Sum $\%$ & 17 & 11 & 12 \\
\hline
\end{tabular}

(Tab. 2) The frequency of kanskje and sikkert among epistemic adverbs.

These data show the variation among epistemic adverbs in L1 and L2 use. In all studied groups of users, kanskje is the main epistemic adverbs, yet its dominance is more visible in case of L2 speakers, where it stands for $76 \%$ of all epistemic adverbs used, while its dominance in the case of L1 speakers is weaker (58\% and 68\%). Still, since the use kanskje stand for more than half of all epistemic adverbs, and sikkert occupies a clear second position, the use of other epistemic adverbs borders on incidental in all three studied groups.

The high frequency of kanskje has made it possible to study the variation in its sentential position, which is shown in table 3 . All positions are illustrated by examples (9-19) following table 3 .

\begin{tabular}{|l|c|c|c|}
\hline $\begin{array}{l}\text { Different positions } \\
\text { of kanskje }\end{array}$ & $\begin{array}{c}\text { L1 speaker in L1 } \\
\text { conversation } \\
\text { (L1-A/B) }\end{array}$ & $\begin{array}{c}\text { L1 speaker } \\
\text { in L2 conversation } \\
\text { (L2-B) }\end{array}$ & $\begin{array}{c}\text { L2 } \\
\text { speaker } \\
\text { (L2-A) }\end{array}$ \\
\hline Prefield & 12 & 23 & 26 \\
\hline Front field (Verb2) & $<1$ & 0 & 3 \\
\hline Middle field & 52 & 35 & 30 \\
\hline Post field & 10 & 17 & 4 \\
\hline Phrasal & 20 & 18 & 25 \\
\hline Single & 6 & 7 & 12 \\
\hline Sum \% & 100 & 100 & 100 \\
\hline
\end{tabular}

(Tab. 3) The sentential positions of kanskje across users and settings.

Prefield:

(9) kanskje det er greit [L2-6B]

'maybe it's ok'

(10) kanskje det blir be- enklere i Norge for barn å gå på skolen [L2-5A] 'maybe it will be be- easier in Norway for children to go to school' 
Front field (Verb2):

(11) ja men ka- men kanskje går det ikke? [L2-8A]

lit. yes but may- but maybe goes it not?

'Yes but maybe it won't work?'

Middle field:

(12) jeg tror kanskje man tok et skrivemaskinkurs [L1-9B]

'I think maybe one took a typing course'

(13) jeg kunne kanskje by litt mer [L2-4A]

'I could maybe offer a bit more'

Post field:

(14) noe seinere med de flisene kanskje? [L1-13A]

'A bit later with those tiles maybe?'

(15) de er vel glad i barn kanskje [L2-7B]

'They like children maybe'

Phrasal scope, in case when the phrase is used outside of a sentence paradigm:

(16) de er litt aktive da syns jeg da kanskje litt bråkete og [L1-12A]

'They are active $d a$ I think $d a$ maybe a bit noisy and'

(17) jeg vet ikke hvilken påvirkning det kan ha det det kanskje i fremtiden [L2-1A]

'I don't know which influence it may have that that maybe in the future'

Single use, often following the answer particle ja 'yes' or standing on its own as a full utterance:

(18) kanskje det? [L2-6A]

maybe that

'maybe it is so?'

(19) ja ka- kanskje jeg vet ikke [L2-3A]

'Yes ma- maybe I don't know'

In general, one can say that the L2 speakers use kanskje in all syntactical positions, contrary to expectations. They seem to prefer clause initial position, which may be due to transfer from their mother tongue, where the Polish equivalent moze is often placed in sentence initial position. Nonetheless, the frequency is similar to the L1 use in L2 conversation, while in L1 conversation 
the frequency of kanskje in prefield is lower (12\%). In L1 conversation, in turn, one observes a stronger preference for the middle field position $(52 \%$ as opposed to $35 \%$ and $30 \%$ in L2 conversation). In order to address the source of this discrepancy one would have to study the examples in more detail, possibly focusing on the speech acts in which the adverb appears (propositions vs. speculations).

Contrary to expectations, the L2 speakers seem to follow the native preference for the lack of Verb2 rule. The few instances of kanskje followed by the inversed sentence order were found in one conversation (L2-8), where the L2 user was also a competent speaker of German. In this case, one can probably attribute the chosen word order to L3 interference.

The percent of norm-breaching uses of kanskje tends to be rather low, as table 4 shows.

\begin{tabular}{|c|c|c|l|}
\hline Conversation & Errors/Uses & $\begin{array}{c}\text { Correctness } \\
\text { score }\end{array}$ & \multicolumn{1}{|c|}{ Types of errors } \\
\hline L2-1 & $0 / 10$ & $100 \%$ & --- \\
\hline L2-3 & $1 / 17$ & $94 \%$ & SVA in subordinate clause \\
\hline L2-4 & $1 / 11$ & $91 \%$ & phrasal instead of sentential scope \\
\hline L2-5 & $0 / 19$ & $100 \%$ & --- \\
\hline L2-6 & $1 / 20$ & $95 \%$ & phrasal instead of sentential scope \\
\hline L2-7 & $1 / 6$ & $83 \%$ & SAV in main clause \\
\hline L2-8 & $0 / 6$ & $100 \%$ & --- \\
\hline L2-9 & $4 / 20$ & $80 \%$ & $\begin{array}{l}\text { SAV in main clause, SVA in } \\
\text { subordinate clause, other word } \\
\text { order }\end{array}$ \\
\hline L2-10 & $1 / 25$ & $96 \%$ & phrasal instead of sentential scope \\
\hline L2-11 & $0 / 4$ & $100 \%$ & --- \\
\hline L2-12 & $0 / 4$ & $100 \%$ & --- \\
\hline L2-13 & $2 / 15$ & $87 \%$ & $\begin{array}{l}\text { SAV in main clause, SVA in } \\
\text { subordinate clause }\end{array}$ \\
\hline L2-14 & $0 / 2$ & $100 \%$ & - \\
\hline All L2 users & $\mathbf{1 1 / 1 5 9}$ & $\mathbf{9 3 \%}$ & \\
\hline
\end{tabular}

(Tab. 4) The norm-breaching uses of kanskje (L2 users).

The average correctness score is $93 \%$, with the individual scores ranging between $80 \%$ and $100 \%$. Of the 11 norm-breaching uses, 3 are examples of wrong sentence order in subordinate clause:

(20) kanskje det passer ikke [L2-3A] correct: kanskje det ikke passer 'maybe it doesn't suit (you)' 
(21) fordi du vet ikke [L2-9A] correct: fordi du ikke vet 'because you don't know'

Another 3 norm-breaching uses are SAV word order in main clause:

(22) det kanskje er femtito [L2-9A] corr. det er kanskje femtito 'it's maybe fifty two'

Another 3 uses show phrasal rather than sentential scope:

(23) skal jeg lage kanskje middag? [L2-4A] correct: skal jeg kanskje lage middag? 'shall I maybe cook supper?'

The last two examples involve a norm breach that goes beyond the position of the adverb or generally the sentence structure, as in the following example:

(24) at kanskje vil en gruppe opprette på Skole2 [L2-9A] correct: at en kanskje vil opprette en sånn gruppe på Skole2 'that maybe one will create such a group in School2'

\subsection{THE USE OF EVIDENTIAL MODAL ADVERBS}

\begin{tabular}{|l|c|c|c|}
\hline & $\begin{array}{c}\text { L1 conversation } \\
(\mathrm{L} 1-\mathrm{A} / \mathrm{B})\end{array}$ & $\begin{array}{c}\text { L1 speakers } \\
\text { in L2 conversations } \\
\text { (L2-B) }\end{array}$ & $\begin{array}{c}\text { L2 speakers } \\
\text { (L2-A) }\end{array}$ \\
\hline egentlig & 69 & 72 & 62 \\
\hline faktisk & 20 & 24 & 31 \\
\hline andre & 11 & 4 & 7 \\
\hline Sum \% & 100 & 100 & 100 \\
\hline
\end{tabular}

(Tab. 5) The frequency of egentlig and faktisk among evidential adverbs.

In the case of L2 speakers, their use of evidential adverbs does not differ from the one observed in L1 talk. The two dominant adverbs are egentlig and faktisk, and the use of other evidential modal adverbs is rather insignificant. A slight preference to use faktisk on the side of L2 speakers may be due to language transfer, as in Polish there is an adverb based on the same root, namely faktycznie. 


\subsection{THE USE OF PARTICLES AND ALTSA}

\begin{tabular}{|l|c|c|c|}
\hline & $\begin{array}{c}\text { L1 conversation } \\
\text { (L1-A/B) }\end{array}$ & $\begin{array}{c}\text { L1 speakers } \\
\text { in L2 conversations } \\
\text { (L2-B) }\end{array}$ & $\begin{array}{c}\text { L2 speakers } \\
\text { (L2-A) }\end{array}$ \\
\hline jo & 36 & 30 & 5 \\
\hline visst & $<1$ & 0 & 0 \\
\hline nok & 1 & 2 & $<1$ \\
\hline vel & 4 & 5 & 4 \\
\hline da & 31 & 36 & 9 \\
\hline altså & 14 & 6 & 3 \\
\hline
\end{tabular}

(Tab. 6) The frequency of altså and particles among all modal markers.

The particles visst, nok and vel are not very often used by L1, and hence their scarce use by L2 speakers does not stand out from the overall tendencies. There is however a striking discrepancy in the frequency of using jo and $d a$ by L1 and L2 speakers. The first item stands for 36\% and 30\% of all modal markers used by L1 speakers in L1 and L2 context, respectively, while the equivalent number in L2 produced talk is $5 \%$. A similar discrepancy can be seen in the case of $d a$, which stands for $31 \%$ and $36 \%$ of all modal markers in L1 produced talk as opposed to $9 \%$ in L2 produced talk. There is however an interesting discrepancy in their employment in talk, as jo appears only in the position traditionally reserved for sentence adverbials, that is sentence medial. The other marker, $d a$, may also appear in that position, but in the studied data such examples stand for only $4 \%$ of uses in L1 produced speech. The dominating use it the post-field $d a$, and the dominance is also realized in the L2 produced talk, though as already mentioned in limited numbers.

The frequency of employing altså does also differ to some extent, yet by no means is the difference as striking as for the two first markers.

In general, one can say that the particles are almost non-existent in the studied L2 talk. Only one L2 user, L2-14A, comes close to a use of particles that is comparable to the one produced by his conversation partner, and which as such may be labelled native-like.

\section{DISCUSSION}

\subsection{ADVERBS}

Contrary to expectations, the data suggest the studied L2 speakers do not differ much from the L1 speakers when it comes to the variation among modal adverbs. The adverb kanskje is clearly dominating among epistemic adverbs, whereas egentlig is the most frequently employed evidential adverb. Neither 
does the syntactic variation of kanskje pose difficulties for the studied L2 speakers (93\% correctness score). It seems that when it comes to employing modal adverbs in their talk, the studied L2 speakers are close to native-like use. Nonetheless, the data does indicate two differences that deserve further investigation. The first one is that the studied L2 speakers use boulomaic adverbs, such as dessverre 'unfortunately', more frequently than L1 speakers. The second one is the L2 speakers' weak preference for using kanskje 'maybe' in sentence initial position, whereas L1 speakers seem to prefer the medial position. Both conclusions are based on very limited data, so they can only be treated as a suggestion for further studies.

Hence, one can say the data does not support hypotheses 1 and 2, posed in point 2 . The range of modal adverbs employed by L2 speakers corresponds to a great extent to the one found in L1 produced speech. The syntactic position of kanskje is as varied in case on L2 speech as it is in the case of L1 data, and the number of norm-breaching uses is rather low (7\% of all occurences).

\subsection{PARTICLES AND ALTSA}

According to expectations, the L2 speakers' talk differed to a great extent from L1 produced talk when it comes to the frequency of using particles. It has been shown that particles and altså represent at least $79 \%$ of all modal markers used by L1 speakers, while the number is $26 \%$ in the case of L2 produced speech. Hence, one can say that hypothesis 3 , posed in point 3 , has been confirmed.

In L1 talk, there seems to be a preference for using jo and $d a$, while the other three particles nok, vel and visst are rather scarce. I will now focus on the two particles that were highly frequent in L1 data and discuss their functions.

As already mentioned, the particle jo can appear in the middle field, as well as in post field. It is interesting to note that none of the analysed instances occupied the post-field position, even though Lind suggests that this usage is frequent in spontaneous everyday talk (1996:186). Hence, all the instances of jo found in this data are clause internal uses. Lind (ibid.:183) has shown that jo in this position is very often a cohesive device, linking the utterance it accompanies with what was said previously. The other function is to signalise that the speaker considers the information inherent in the proposition as known for the recipient. As such, it is considered a marker of common ground. What is interesting is that the particle "not seldom appears together with information that must be seen as new for the recipient" (ibid.:184, my translation). Lind interprets such use as a means of creating pseudo-intimacy, which would suggest the particle performs a vital function related to the politeness strategy of preserving the recipient's positive face by referring to shared knowledge, even if this sharedness is only presupposed. Such use of the particle jo can also 
be observed in my data, as the particle is not infrequent in conversations among strangers. The following example appears in a passage where the L2 speaker (1A) discusses health care systems in Norway and Poland, and introduced the system in USA as a comparison. The L1 speaker (1B) joins the topic by giving her reasons for being knowledgeable in this respect.

(25) i USA ja (...) i USA så jeg har jo slektninger i USA og de forteller [L2-1B] 'in the USA yes (...) in the USA so I have jo relatives in the USA and they say'

Another feature worth mentioning is the high frequency of the particle in L1 talk, in several conversations, both L1 and L2 context. For instance in the conversation labelled as L2-4, the L1 speaker uses jo 65 times (which stands for $46 \%$ of all modal markers used by this speaker), and very often in sentences following one another, as in example 26.

(26) og det var jo og stått der siden 50-tallet ikke sant så den var jo sånn gulna da blir jo svært mørkt da når den er blitt helt sånn gulbrun [L2-4B] 'and it has stood there since the fifties right so it was jo like yellow it becomes jo very dark when it has become completely yellowish brown'

It is interesting to note that this passage comes from the part of conversation when the speaker is describing her summerhouse that her conversational partner has not seen. On the other hand, the use of jo in the second part of the utterance is probably contextually grounded in the first statement regarding the age of the house.

In view of the observed discrepancy in using the particle jo by L1 and L2 speakers, it is a valid question to ask what it means that the studied L2 speakers do not employ this particle in their talk. It would be rash to claim that they can be perceived as impolite by exposing their conversational partner's face, yet it is certainly a possibility that cannot be excluded. On the other hand, it is not impossible that the L2 speakers are capable of using the particle jo in a formally and functionally correct way, yet they fail to see the objective of presenting information obviously new to their conversational partners as shared knowledge. From an extreme point of view one can judge such practice as being untruthful or false. Lind (1996: 186) has found instances of using the particle in political debates, which can be perceived as manipulative: the speaker is trying to establish a common ground so that the recipient is forced to accept the point of view of the speaker. On the basis of my data it is hard to decide the reasons for the L2 speakers' not using jo in their talk, but it would certainly be worth investigating in a more experimental way.

The other particle that is highly frequent in L1 data is $d a$. As the post field use accounts for more than $90 \%$ of all occurrences of $d a$ in L1 talk, I will now focus on the functions of this usage. It is often labelled 'inference particle', yet 
this label does not seem to cover all the functions. Borthen says that post field $d a$ is "a linguistic chameleon that changes character depending on the context" (2014:257, my translation). For Fretheim (2014), the particle $d a$ codes an interpretation that the proposition modified by it is mutually manifest for both speaker and listener, and as such would place the function of $d a$ close to jo. Borthen (2014:271) however, shows how this definition is not complete, pointing to important restrictions on the use of $d a$ compared to jo. As a consequence, she suggests a following definition of $d a$ :

The semantics of the word instructs the receiver to interpret the utterance in the light of an inference which involves the proposition and another contextually available presupposition, and to interpret the utterance in the light of different points of view being contrasted. (Borthen 2014:299, my translation)

In other words, the utterance accompanied by $d a$ is to be interpreted as anchored either in shared knowledge or in previous discursive history. In the same time, it expresses an opinion that is somehow contrastive to other points of view. Borthen lists 8 contexts of post-field $d a$ that she has identified in her data corpus (op.cit.:298), and those include $d a$ following a yes/no question, a wh-question, an imperative and others. For instance, a yes/no-question accompanied by $d a$ will convey a doubt on the point of the speaker that the proposition inherent in the utterance is truthful, while a $d a$ following an answer particle $j a$ will signal that the answer is seen as expected or desired. One could say that the post-field $d a$ plays a vital role in signalling minute differences in the way conversational partners perceive and frame their talk within a broad context.

The last item discussed in this section is altså. As already mentioned, it may appear in clause initial position (prefield) and is then considered primarily as a conjunctional adverb, whereas in the middle and post field position, its meaning is primarily modal. According to Fretheim (2015:253), in the post field position both $d a$ and altsa "occur in assertive speech acts and in requests for confirmation". The difference between the items is the speaker's degree of confidence about the epistemic attitude to the proposition: "Altså encodes the speaker's strong belief that the hearer's propositional attitude at the time of utterance is supportive of the host sentence proposition" (op.cit.). In contrast, the use of post field $d a$ instead accompanies propositions "which the speaker infers that the hearer believes to be true, but which the speaker is not prepared to endorse" (op.cit.). In other words, while altså encodes a high degree of epistemic conviction, $d a$ signals a broader spectrum of epistemic beliefs, from conviction (in the middle field) to doubt (in the post field, Fretheim 2014:245).

The modal markers analysed in point 5.2 are highly infrequent in the studied L2 data. Their semantics is not only difficult to grasp, but also seems highly dependent on the cognitive processing of the content of the talk. As such, 
they are likely to be difficult to acquire by L2 speakers. At the same time, due to their frequency and functions described above, they can be considered important in achieving one's communicative goals in a conversation.

\section{CONCLUSIONS AND IMPLEMENTATION}

The study has shown that when it comes to the field of modal marking in conversation, the L2 produced talk is indeed different than the L1 produced. As the frequencies of using modal adverbs are similar for L1 and L2 speakers, the difference lies primarily in the use of particles. On the basis of the study it is impossible to discuss the reasons for this fact. It could be connected to linguistic transfer, as Polish does not have such a clear-cut category of modal particles. To corroborate this hypothesis one would have to find Norwegian as L2 speakers with a different L1. German users of Norwegian would be a useful control group, as German exhibits a similar group of modal markers that are also highly frequent in everyday conversation.

It is difficult to answer the question of the impact that the lack of using particles by L2 speakers has on their achieving communicative goals. In order to address this issue, one would probably have to conduct experimental studies in which L1 users judge different utterances on the scale of appropriateness, politeness and successfulness. Another experimental study could address the reasons for not using particles even by advanced L2 users.

The study also has didactic implementation. Apart from dealing with the form (word order), the modal markers do not receive much attention from Norwegian as L2 researchers, nor are they explicitly included in teaching materials. Borthen et al. (2016) have studied the possibility of teaching the pragmatics of post-field 'da', and found that the explicit instruction had little impact on the understanding of the particle's function. At the same time, the students who participated in the study have shown positive attitude to being instructed in this specific area of language use. Their findings would suggest that the use of particles is viewed by L2 users as rather important, yet difficult, both to acquire and to teach. Their frequency, however, is so high that not using them may be seriously impeding L2 users from achieving their conversational goals.

\section{REFERENCES}

Aijmer, K. (2013). Analyzing modal adverbs as modal particles and discourse markers. In: L. Degand, B. Cornillie, P. Pietrandrea (eds.) Discourse markers and modal particles: categorization and description (pp. 89-106). Amsterdam/Philadelphia: John Benjamins.

Bentzen, K. (2007). The degree of verb movement in embedded clauses in three varieties of Norwegian. In: K. Bentzen \& Ø. Vangsnes (eds.), Nordlyd 34, 127-146.

Borthen, K. (2014). Hva betyr 'da', da? Norsk lingvistisk tidsskrift 32, 257-306. 
Borthen, K., Ree N. A., Robbins, S. (2016). Pragmatiske partikler i norsk som andrespråk: Hvordan undervise om etterstilt 'da'? Presentation at the 7th national conference on Norwegian as a second language, Trondheim.

Bybee, J., Perkins, R, Pagliuca, W. (1994). Mood and modality. In: J. Bybee, R. Perkins, W. Pagliuca (eds.) The evolution of grammar: Tense, aspect, and modality in the languages of the world (pp. 176-242). Chicago: The University of Chicago Press.

Cuenca, M. (2013). The fuzzy boundaries between discourse marking and modal marking. In: L. Degand, B. Cornillie, P. Pietrandrea (eds.) Discourse markers and modal particles: categorization and description (pp. 191-216). Amsterdam/Philadelphia: John Benjamins.

von Fintel, K. (2006). Modality and Language. In: D. Borchert (ed.) Encyclopedia of Philosophy - Second Edition, Detroit: MacMillan Reference USA. Most recent version online at http://mit.edu/fintel/www/modality.pdf.

Fischer, K., Alm, M. (2013). A radical construction grammar perspective on the modal particlediscourse particle distinction. In L. Degand, B. Cornillie, P. Pietrandrea (eds.) Discourse markers and modal particles: categorization and description (pp. 47-88). Amsterdam/Philadelphia: John Benjamins.

Fretheim, T. (2014). Et relevansteoretisk blikk på likheter og forskjeller mellom partiklene $d a$ og altså. Norsk lingvistisk tidsskrift 32, 197-256.

Fretheim, T. (2015). A relevance theoretic perspective on the Norwegian utterance-final particles $d a$ and altså compared to their English counterpart then. In: S. Hancil, A. Haselow, M. Post (eds.) Final particles (pp. 249-283). Berlin/Boston: Mouton de Gruyter.

Faarlund, J. T., Lie, S., Vannebo, K. I. (1997). Norsk referansegrammatikk. Oslo: Universitetsforlaget.

Gardner, R., Wagner, J. (eds.) (2004). Second language conversations. Bloomsbury Academic.

Horbowicz, P. (2010). How to be Norwegian in talk? Polish-Norwegian interethnic conversation analysis. Oslo: Novus.

Johannessen, J., Hagen, K. (2008). Om NoTa-korpuset og artiklene i denne boka. In: J. Johannessen, K. Hagen (eds.) Språk i Oslo. Ny forskning omkring talespråk (pp. 7-14). Oslo: Novus.

Lind, M. (1996). Pragmatiske partikler i diskursanalytisk perspektiv. Bruken av partikkelen jo i et norsk talemålsmateriale. In: K. Ottoson, R. Fjeld, A. Torp (eds.): The Nordic Languages and Modern Linguistics. Proceedings of The Ninth International Conference of Nordic and General Linguistics. University of Oslo, January 11-12, 1995 (pp. 177-190). Oslo: Novus.

Mac Donald, K. (1990). Når man mangler førstehåndskjennskap - en studie i modalitet; Små ord med stor betydning. In: A. Golden, K. Mac Donald, B. Michalsen, E. Ryen, Hva er vanskelig i grammatikken? Sentrale emner i norsk som andrespråk (pp. 50-72). Oslo: Universitetsforlaget.

Nuyts, J. (2001). Epistemic modality, language and conceptualization. Amsterdam/Philadelphia: John Benjamins.

Nuyts, J. (2016). Analyses of modal meaning. In: J. Nuyts, J. van der Auwera (eds.). The Oxford Handbook of Modality and Mood (pp. 31-49.) Oxford University Press.

Palmer, F. R. (2001) [1986]. Mood and modality. Second Edition. Cambridge University Press.

Portner, P. (2009). Modality. Oxford University Press.

Sandøy, H. (2008). Norske syntaktiske "avvik" i norsk. In: C. Carlsen, E. Moe, R. Andersen, K. Tenfjord (eds.), Banebryter og brobygger $i$ andrespråksfeltet. En samling artikler $i$ anledning Jon Erik Hagens 60-årsdag (pp. 179-190). Oslo: Novus.

Sarangi, S. (1994). Intercultural or not? Beyond celebration of cultural differences in miscommunication analysis. Pragmatics 4:3, 409-427.

Svensson, S. (2012). Modalitet og rammeverksnivå. In: C. Carlsen (ed.) Norsk profil. Det felles europeiske rammeverket spesifisert for norsk. Et første steg (pp. 159-187). Oslo: Novus.

Tenfjord, K., Hagen, J. E., Johansen, H. (2009) Norsk andrespråkskorpus (ASK) - design og metodiske forutsetninger. NOA Norsk som andrespråk 25/1, 52-81. 
Traugott Closs, E. (2007). Discourse Markers, Modal Particles, and Contrastive Analysis, Synchronic and Diachronic. Catalan Journal of Linguistics 6 (Special issue: Contrastive Perspectives on Discourse Markers, ed. by Maria Josep Cuenca.), 139-157.

Uri, H. (1999). Pragmatiske partikler i et andrespråksperspektiv. Norsk lingvistisk tidsskrift 17, 139-154.

Wagner, J. (1996). Foreign language acquisition through interaction - A critical review of research on conversational adjustments. Journal of Pragmatics 26, 215-235.

Westergaard, M. (2009). Microvariation as diachrony: A view from acquisition. Journal of Comparative Germanic Linguistics 12.1, 49-79.

NoTa-Oslo: Norwegian Speech Corpus - the Oslo part: http://www.tekstlab.uio.no/nota/oslo

\section{Paulina Horbowicz}

Uniwersytet im. Adama Mickiewicza w Poznaniu

Katedra Skandynawistyki

al. Niepodległości 4

61-874 Poznań

Poland

phorbo@amu.edu.pl 


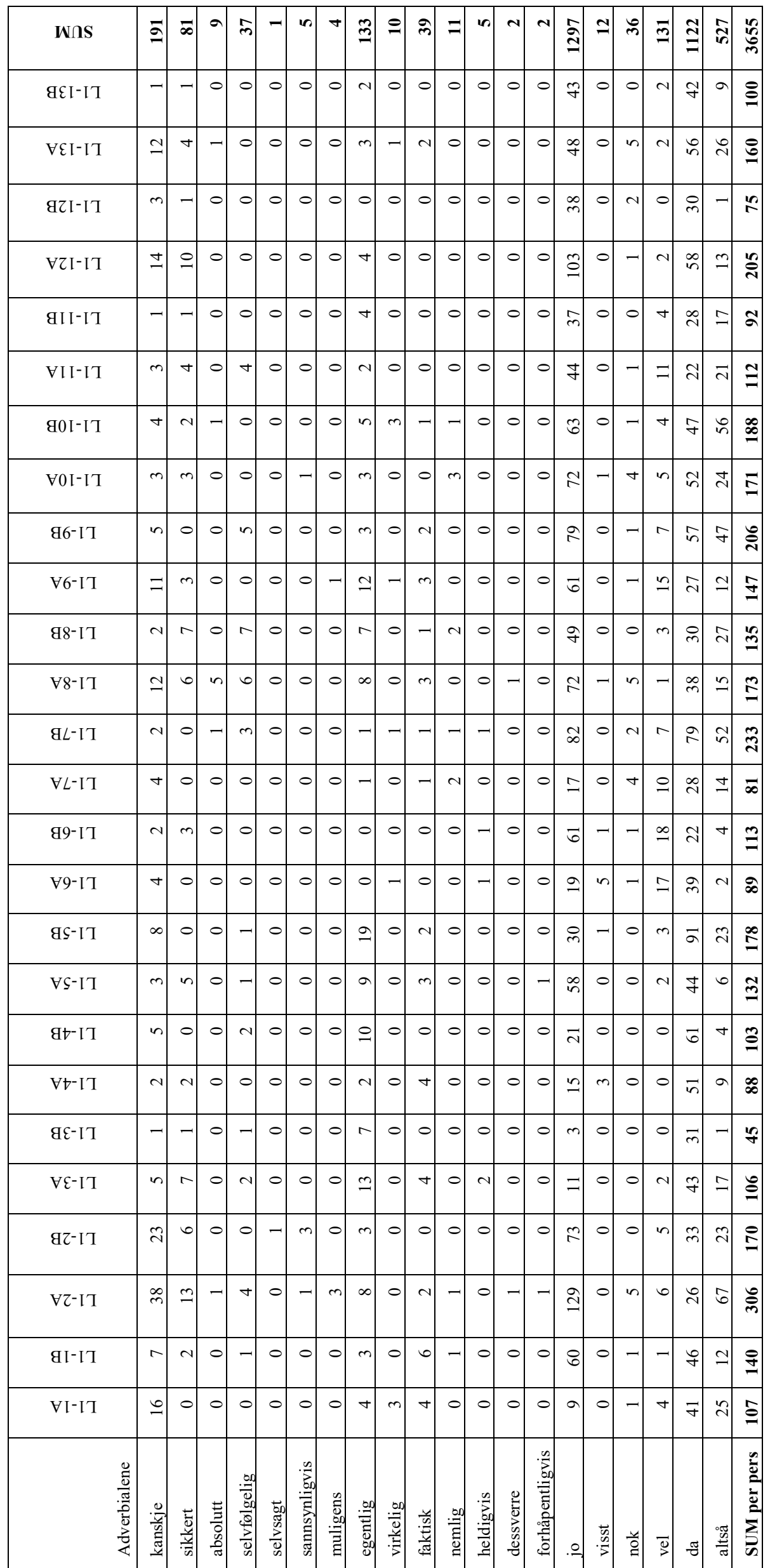




\begin{tabular}{|c|c|c|c|c|c|c|c|c|c|c|c|c|c|c|c|c|c|c|c|c|c|c|}
\hline g WOS & $\infty$ & 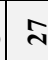 & i) & $=$ & $y=$ & $b$ & 0 & -1 & $\stackrel{\infty}{+}$ & 0 & $m$ & 0 & 0 & - & 0 & 今心 & - & 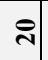 & $\nexists$ & ల్లి & in & $\underset{\kappa}{\infty}$ \\
\hline$\forall$ WOS & in & $\mathscr{\sim}$ & $\infty$ & 0 & $\theta=$ & & $N$ & 0 & ले & $\bullet$ & $m$ & - & $N$ & $\simeq$ & - & $\stackrel{\infty}{-\infty}$ & 0 & $m$ & $\bullet$ & f & $\cong$ & $\underset{m}{+}$ \\
\hline gtI-ZT & - & - & -0 & $\circ$ & $v e$ & & 0 & 0 & - & $m$ & 0 & 0 & 0 & 0 & 0 & $\infty$ & 0 & $\sim$ & $m$ & 2 & 0 & 8 \\
\hline$\forall t I-\tau T$ & $\tau$ & - & -0 & 0 & $\circ 0$ & & 。 & 0 & $N$ & 0 & 0 & 0 & - & 0 & 0 & $=$ & 0 & 0 & - & 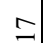 & $N$ & m \\
\hline gદા-てT & 은 & N & 10 & 0 & $\circ 0$ & & 0 & 0 & $m$ & - & 0 & 0 & 0 & 0 & 0 & 2 & 0 & - & $n$ & $\infty$ & $\simeq$ & 8 \\
\hline$\forall \mathcal{~} \mathrm{I}-Z]$ & $n$ & $\mathrm{~N}$ & o & 0 & 0 & & 0 & 0 & 0 & 0 & 0 & 0 & 0 & 0 & 0 & 0 & 0 & - & $N$ & - & 0 & $\bar{v}$ \\
\hline gว I-ZT & 0 & 0 & o & $5-$ & -0 & & 0 & 0 & 0 & $N$ & 0 & 0 & 0 & 0 & 0 & $\nabla$ & 0 & - & $n$ & $\stackrel{\infty}{\sim}$ & $N$ & $m$ \\
\hline$\forall Z I-Z T$ & $\nabla$ & 0 & o & 0 & v $O$ & & o & 0 & $N$ & $\nabla$ & 0 & 0 & 0 & 0 & - & 0 & 0 & 0 & 0 & $m$ & - & ते \\
\hline яІ I-ZТ & $\infty$ & - & -0 & $0-$ & -0 & & o & 0 & $r$ & $N$ & 0 & 0 & 0 & 0 & 0 & $\because$ & 0 & $m$ & $N$ & $\approx$ & $\nabla$ & $\infty$ \\
\hline VII-ZT & $\nabla$ & - & -0 & 0 & 0 & & 0 & 0 & - & 0 & 0 & 0 & 0 & 0 & 0 & - & 0 & 0 & - & $\nabla$ & $N$ & \pm \\
\hline g0I-Zา & $m$ & $m$ & o & 0 & 0 & & 0 & 0 & $N$ & 0 & 0 & 0 & 0 & 0 & 0 & $m$ & 0 & 0 & $N$ & $\simeq$ & - & 눈 \\
\hline V0I-ZT & $\stackrel{2}{n}$ & - & 0 & 0 & 0 & & o & 0 & $=$ & 0 & 0 & 0 & 0 & 0 & 0 & 0 & 0 & - & 0 & - & $N$ & 于 \\
\hline g6-乙ד & - & $\nabla$ & - & -0 & 0 & & 。 & 0 & $\nabla$ & 0 & 0 & 0 & 0 & - & 0 & $\nabla$ & 0 & 0 & $N$ & $=$ & + & ले \\
\hline V6-ZT & $\approx$ & - & -0 & $0 r$ & $n$ & & 0 & 0 & 0 & $N$ & 0 & 0 & 0 & $\sim$ & 0 & 0 & 0 & 0 & - & 0 & 0 & 2 \\
\hline g8-z7 & $n$ & 0 & o & 0 & $n$ & & ○ & 0 & 0 & - & - & 0 & 0 & 0 & 0 & q & 0 & 0 & 0 & ชื & $r$ & $\underset{m}{\infty}$ \\
\hline V8- $\tau T$ & v & 0 & o & o- & -10 & & 0 & 0 & $m$ & 0 & 0 & 0 & 0 & 0 & 0 & - & 0 & 0 & 0 & $\sim$ & 0 & 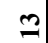 \\
\hline $\mathrm{g} \angle-\tau \mathrm{T}$ & 9 & 0 & c & $\circ-$ & -0 & & 0 & 0 & $\nabla$ & $N$ & 0 & 0 & 0 & 0 & 0 & $\infty$ & 0 & 0 & $\infty$ & $\underset{m}{\infty}$ & - & $\infty$ \\
\hline$\forall L-\tau T$ & 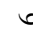 & $m$ & 0 & $\circ-$ & -0 & & 0 & 0 & 0 & 0 & 0 & 0 & 0 & - & 0 & 0 & 0 & 0 & 0 & 0 & 0 & $=$ \\
\hline g9-zา & $\subseteq$ & t & 0 & 0 & -0 & & o & 0 & $N$ & 0 & 0 & 0 & 0 & 0 & 0 & - & 0 & - & $m$ & mे & 0 & $\tilde{\sigma}$ \\
\hline V9-ZT & $\approx$ & r & - & -7 & -10 & & $N$ & 0 & 0 & 0 & 0 & 0 & 0 & 0 & 0 & $m$ & 0 & 0 & $m$ & $r$ & - & 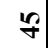 \\
\hline gs-zT & $t$ & $r$ & $o$ & 0 & 0 & & 0 & 0 & $\infty$ & $N$ & 0 & 0 & 0 & 0 & 0 & ㄴ. & 0 & 0 & - & 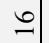 & - & 6 \\
\hline$\forall \varsigma-Z T$ & $\stackrel{\circ}{\circ}$ & o & o & 0 & 0 & & 0 & 0 & 0 & 0 & 0 & 0 & 0 & 0 & 0 & 0 & 0 & 0 & 0 & 0 & 0 & 2 \\
\hline G๖-乙T & $m$ & $m$ & 0 & 0 & 0 & & 0 & 0 & $N$ & 0 & 0 & 0 & 0 & 0 & 0 & 6 & 0 & $m$ & $\nabla$ & $\vec{n}$ & 의 & $\Xi$ \\
\hline$\forall t-\tau T$ & $=$ & $N$ & - & -0 & 0 & & 0 & 0 & $m$ & 0 & $N$ & 0 & 0 & - & 0 & - & 0 & - & 0 & $m$ & $m$ & $\underset{\sim}{\infty}$ \\
\hline 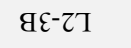 & r & o & o & o - & -0 & & 。 & - & $a$ & $m$ & 0 & 0 & 0 & 0 & 0 & $\vec{\sim}$ & 0 & - & $N$ & $\cong$ & 0 & 8 \\
\hline$\forall \varepsilon-Z T$ & $=$ & - & $o$ & 0 & 0 & & 0 & 0 & $r$ & $N$ & 0 & - & 0 & 0 & 0 & 0 & 0 & 0 & 0 & $\infty$ & $N$ & $\infty$ \\
\hline gI-ZT & $\simeq$ & $N$ & 10 & 0 & v $c$ & & ○ & 0 & 0 & 0 & $N$ & 0 & 0 & 0 & 0 & 아 & - & $\infty$ & $n$ & i & $=$ & $\stackrel{n}{=}$ \\
\hline$\forall I-Z T$ & 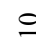 & 6 & c & 0 & 0 & & 0 & 0 & $m$ & $N$ & - & 0 & - & $\sim$ & 0 & - & 0 & 0 & $N$ & - & 0 & 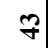 \\
\hline & $\frac{0}{v}$ & 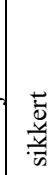 & 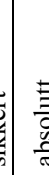 & 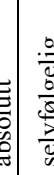 & 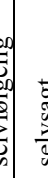 & 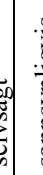 & 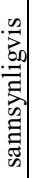 & 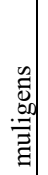 & 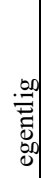 & 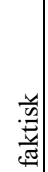 & 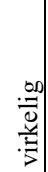 & 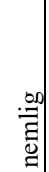 & $\left|\begin{array}{c}0 \\
0 \\
.00 \\
0 \\
0 \\
0\end{array}\right|$ & $\left|\begin{array}{l}0 \\
\stackrel{0}{0} \\
0 \\
0 \\
0 \\
0\end{array}\right|$ & 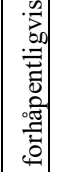 & $\therefore$ & 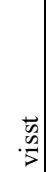 & 前 & $\vec{D}$ & $\pi$ & $\begin{array}{l}\stackrel{0}{0} \\
\frac{0}{\tau}\end{array}$ & $\begin{array}{l}0 \\
\vdots \\
\vdots \\
\vdots \\
\vdots \\
\vdots \\
\vdots \\
\vdots\end{array}$ \\
\hline
\end{tabular}

